\title{
PREDICTION OF DIEBACK DISEASE OF DALBERGIA SISSOO (SHISHAM) BASED UPON ENVIRONMENTAL FACTORS AND TREE AGE
}

\author{
AHMAD, I. ${ }^{1 *}$ - ATIQ, M. ${ }^{2}$ - NAWAZ, M. F. ${ }^{1}-$ AHMED, S. ${ }^{3}-$ ASIF, M. ${ }^{1}-$ GULL, ${ }^{4}{ }^{4}-$ TANVIR, M. A. $^{1}-$ \\ ABDULLAH, M. ${ }^{5}-$ AZHAR, M. F. ${ }^{6}-$ RAJPUT, N. A. $^{2}$ \\ ${ }^{1}$ Department of Forestry and Range Management, University of Agriculture, \\ Faisalabad 38000, Punjab Province, Pakistan \\ ${ }^{2}$ Department of Plant Pathology, University of Agriculture, Faisalabad, Punjab, Pakistan \\ ${ }^{3}$ Department of Plant Pathology, University College of Agriculture, University of Sargodha, \\ Sargodha, Pakistan \\ ${ }^{4}$ Department of Botany, University of Karachi, Karachi, Pakistan \\ ${ }^{5}$ Cholistan Institute of Desert Studies, The Islamia University of Bahawalpur, \\ Bahawalpur, Pakistan \\ ${ }^{6}$ Department of Forestry, Range and Wildlife Management, Bahauddin Zakariya University, \\ Multan, Pakistan \\ *Corresponding author \\ e-mail:irfan_uaf@yahoo.com,irfanahmad@uaf.edu.pk; phone:+92-333-650-2933
}

(Received $20^{\text {th }}$ Jan 2019 ; accepted $4^{\text {th }}$ Mar 2019)

\begin{abstract}
Dieback of forest trees is considered as serious problem in most parts of the world. Shisham an important multipurpose tree of the Indian subcontinent is suffering from dieback. Changing climate in most parts of the world is considered an important factor of ecosystem disturbance. Impact of environmental variables, tree age and water table on the dieback of shisham was examined in different regions of Punjab, Pakistan. Significant correlation was observed between environmental variables and dieback in minimum, moderate and maximum infected trees among three age classes. Water table and rainfall expressed non- significant correlation. A multiple regression model was developed to determine the relationship between environmental variables and dieback. Coefficient of determination value $\left(\mathrm{R}^{2}=0.89\right)$ depicts that model is statistically good. Model indicated that most of the predictor variables has minor role in disease development except age and time span. With one unit increase in age and time span disease will increase 4.15 and 5.25 units respectively. Values of partial R-square indicated that age class (0.5253), time span (0.2943) and relative humidity (0.0552) are major contributors in disease development. It was concluded form the study that age and time span are significant predictor of dieback. Keywords: characterization, disease incidence, correlation, climatic factors, predictive model
\end{abstract}

\section{Introduction}

Dieback of forest trees is a periodic event caused by premature loss of tree health and forest stand vitality (Clatterbuck, 2006). Forest decline and dieback have been reported from different forest ecosystems and climatic zones of the world (Lowman, 1991; Jump et al., 2006) and in the recent past mortality rate has increased in many forest ecotypes of the world (Hosking, 1989; Jursik, 2004). Natural disturbances, including biotic and abiotic stresses are inherent components of forest ecosystems affecting their functioning and biodiversity (Boydet et al., 2013; Thom and Seidl, 2016). About two to three 
decades ago dieback of Dalbergia sissoo was reported in different regions of Pakistan (Ciesla, 1994). D. sissoo being a nitrogen fixing tree and multiple uses is an important tree of social forestry with good economic returns (Lal and Singh, 2012; Ahmad et al., 2013; Farooq et al., 2018; Rashid et al., 2019). Dieback is a major threat to this multipurpose tree (Ahmad et al., 2016, 2017) and has affected millions of trees in Southern Asia (Vogel et al., 2011). Symptoms of shisham dieback are approximately similar to dieback of mango in southern Punjab of Pakistan (Khan et al., 2014) Climate change, fungal pathogens and nutrient deficiencies have been considered as the major causes of tree decline and dieback (Simpson, 1993; Rajput et al., 2008). In different regions of the world fungal pathogens have been recognized as the responsible causal organisms of tree decline and climate change has also been find associated with forest dieback (Ahmad et al., 2016). Environmental stresses contribute to tree mortality and occurrence of forest diseases due to different pathogens will probably become more common and severe in the near future, as different biotic and abiotic factors are strongly influenced by climatic change (Sturrock et al., 2011; Raza et al., 2015). Dieback in northern hardwood forests was strongly linked with the global climatic change; the coefficient of determination value $(\mathrm{R} 2=0.49)$ in the regression analysis showed that climatic changes were responsible for $49 \%$ of the dieback occurring in northern hardwood forests (Auclair et al., 2005). An increasing trend in the forest mortality and dieback due to drought was observed. the linear regression model suggested a very strong association between tree mortality and drought conditions due to low rainfall and high temperature (Phillips et al., 2009; Allen et al., 2010). The extent of forest dieback linked with global climate change would be greater than that observed in the past (National Research Council, 2001). High rate of shisham mortality in India was linked with changing climatic conditions, such as increased drought, extremes of winter and summer, with severe foggy conditions which adversely affected the photosynthesis and other physiological processes of the trees (Singh, 1980; Kaushal et al., 2002).

Age is also considered an important factor in development of forest dieback. Nepstad et al. (2008) reported that as trees are perennial woody plants which grow slowly but the mortality rate of trees was very much higher, even within a period of few months as compare to its growth rate which is very interesting. Older trees were more susceptible to dieback compared with younger trees (Auclair et al., 2010). Little scientific information is known about the spread and development of the disease in individual forest trees in different age groups (Timmermann et al., 2017). Sperry et al., 1991 suggested that in older trees, the membranes associated with vessels and tracheids rupture easily under ecological stresses. Acharya and Subedi (2000) recorded mortality of over-mature dieback-affected $D$. sissoo trees in a short period of even few weeks. Along with tree age, certain species of fungi, such as $F$. solani and $G$. lucidum, killed over $20 \%$ of older trees of D. sissoo under abiotic stresses in Bihar (Chaturvedi et al., 2002).

The effective use of chemical agents against plant diseases requires knowledge of the epidemiology of disease. Understanding disease dynamics, including the pathogen life cycle, provides the basis for forecasting disease outbreaks. Because shisham decline massively reduces both the economic gains and the social uses of this tree, the aim of integrated disease management must be to reduce these losses. Approaches are required which aim to avoid frequent recurrence of shisham decline epidemics. Much research, therefore, remains to be done. Disease severity in relation to different age classes of shisham has not been assessed, and no correlation has been determined between disease 
occurrence and the water table. The impact of varying environmental conditions in relation to spread of disease has not been studied quantitatively. Therefore the objective of study was to assess the relationship between shisham dieback, environmental variables and tree age.

\section{Materials and methods}

\section{D. sissoo dieback disease data collection}

A comprehensive survey of different $D$. sissoo (shisham) growing regions of Punjab province of Pakistan was carried out to collect the data regarding incidence of dieback disease (Fig. 1). Data were collected for the three consecutive years. Furthermore on the basis of disease severity we categorized the trees into three categories i.e. minimum infected, moderately infected and dead or fully affected trees.

\section{Characterization of environmental factors conducive for shisham dieback in field conditions}

Data collected for the incidence of shisham dieback from the different ecological zones of Punjab were subjected to correlation analysis with different climatic variables. The influence of each environmental variable (maximum and minimum air temperature, rainfall, relative humidity wind velocity, age and water table) on the severity of shisham dieback occurrence was determined by correlation.

\section{Regression analysis}

Regression analysis was used to determine any link between environmental/climatic factors and disease incidence/development (Chatterjee and Hadi, 2006). There are two types of models i.e. simple and multiple regression models (Eqs. 1 and 2). For developing simple linear regression models, the response variable (Y), in this case disease, was a function of the single predictor or explanatory variable (X), here an environmental/climatic variable. The equation for simple linear regression is:

$$
\mathrm{Y}=\beta 0+\beta 1 \mathrm{X}
$$

where $\beta 0$ is the intercept and $\beta 1$ is the slope. In multiple linear regression, however, there are more explanatory or predictor variables when compared with simple linear regression. The relationship is described by:

$$
\mathrm{Y}=\beta 0+\beta 1 \mathrm{x} 1+\beta 2 \mathrm{x} 2+\cdots+\beta \mathrm{i} \mathrm{xi}+\epsilon
$$

where $\mathrm{x}$ represents the collection of $\mathrm{i}$ predictors $\mathrm{x} 1, \mathrm{x} 2, \ldots \mathrm{xi}$ in the model, and $\beta 1$, $\beta 2, \ldots \beta i$ are the corresponding regression coefficients and $\epsilon$ is the random error or disturbance.

\section{Development of disease predictive model for the field study}

A predictive model for the field data on disease incidence and severity was also developed. Weekly environmental data comprising of maximum and minimum air 
temperatures, relative humidity, average rainfall and wind speed were collected from the Regional Meteorological Station, Lahore. All the collected environmental data, tree age, underground water table data and dieback disease incidence data in the different districts of Punjab (Faisalabad, Lahore, Sargodha, Sahiwal, Okara, Rawalpindi, Multan, Bahawalpur, Rahim yar khan and Dera Ghazi Khan) from November 2009 to April 2010 and the same months during 2010-11, were subjected to analysis of variance to evaluate the effect of abiotic factors on disease incidence by using the Least Significant Difference Test (LSD at $\mathrm{P}<0.05)$.

The influence of these environmental conditions on disease severity was determined by correlation analyses (Steel et al., 1997). $\mathrm{R}^{2}$, Mallows $\mathrm{Cp}$ and mean square error (MSE) were the criteria used to select the best models (Khan and Illayas, 1999).
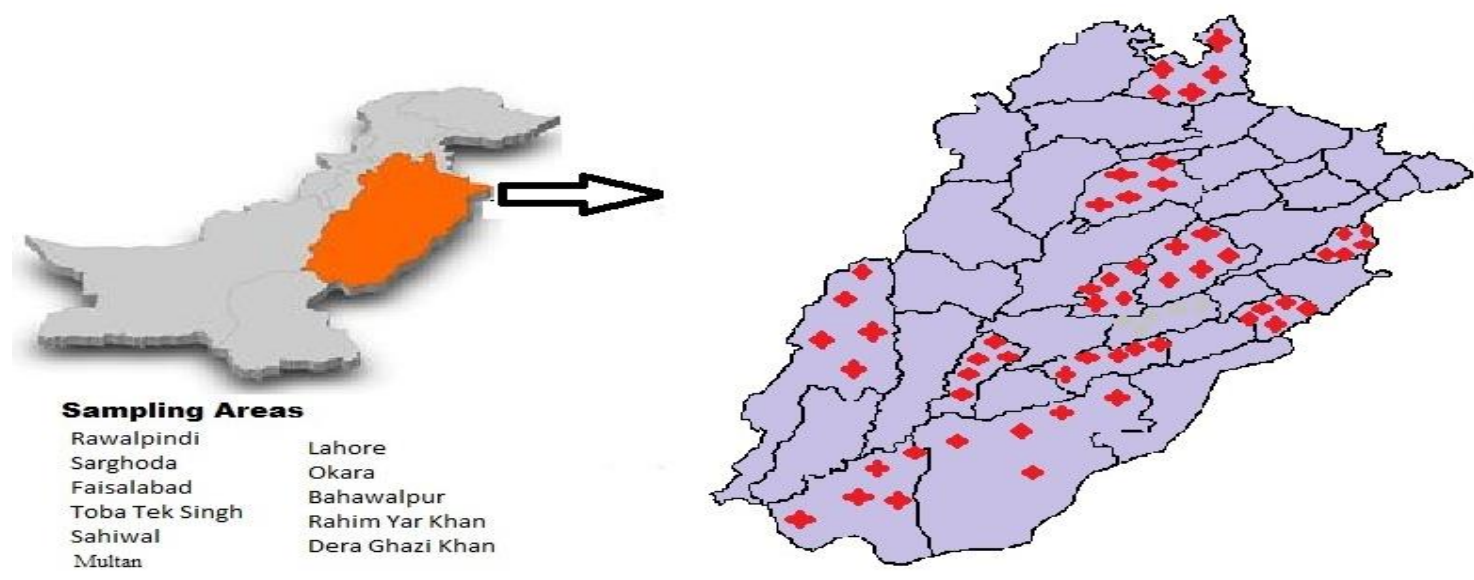

Figure 1. Study area map showing eleven districts of Punjab province

\section{Results}

Correlation between environmental variables and host (minimum, moderate and maximum infected trees of shisham) in different ecological zones of Punjab

There was a significant correlation between environmental variables (rainfall, relative humidity, minimum temperature, maximum temperature, wind velocity and water table) and host (minimum, moderate and maximum infected with dieback disease) of three age classes in different areas of Punjab $(P<0.05)$. Water table and rainfall expressed non-significant correlation with dieback disease in all categories of host (minimum, moderate and maximum infected with dieback). A weak and negative association was found between maximum temperature and minimum infected $(\mathrm{r}=$ $0.190)$, positive in moderately infected $(r=0.176)$ and fully infected trees $(r=0.175)$ followed by wind velocity in minimum infected $(\mathrm{r}=-0.166)$, moderately affected $(r=0.184)$ and fully infected trees (0.129). Similar results were expressed by maximum temperature (minimum infected, $\mathrm{r}=-0.105$; moderately infected, $\mathrm{r}=0.150$; maximum infected, $r=0.138)$ and relative humidity in minimum infected $(r=0.106)$, moderately infected $(\mathrm{r}=-0.125)$ and maximum infected $(\mathrm{r}=-0.076)$ trees (Figs. 2, 3 and 4).

Regression analyses of environmental variables against dieback disease were carried out independently to observe the effects of each environmental variable separately on the disease development in the major shisham grown areas of the Punjab province. Table 1 showed the regression equations and $\mathrm{R}^{2}$ of the correlations of environmental 
variables with the minimum trees. $\mathrm{R}^{2}$ value shows that $39.2 \%$ of variation in dieback disease was explained by the host categories', followed by time span (20.5\%), maximum temperature $(3.6 \%)$, wind speed $(2.7 \%)$, minimum temperature $(2.4 \%)$, relative humidity $(1.1 \%)$, rainfall $(0.3 \%)$ and water table $(0.2 \%)$. For minimum infected trees, category of host was responsible for $29.1 \%$ of variation, followed by time $(15.7 \%)$, wind speed $(3.4 \%)$, maximum temperature $(3.0 \%)$, minimum temperature $(2.2 \%)$, relative humidity $(1.5 \%)$, water table $(0.2 \%)$; rainfall did not explain any variation. Similar trend was detected in maximum infected trees, where as $37.6 \%$ variation was explained by age class, followed by time span (18.6\%), maximum temperature $(3.1 \%)$, minimum temperature $(1.9 \%)$, wind speed $(1.7 \%)$, relative humidity $(0.6 \%)$, rainfall $(0.5 \%)$ and $0.2 \%$ by water table.

Table 1. Regression equations of minimum, moderate and maximum infected trees with different variables

\begin{tabular}{|c|c|c|c|c|c|c|c|c|}
\hline \multicolumn{9}{|c|}{ Categories of host } \\
\hline \multicolumn{3}{|c|}{ Trees with minimum infection } & \multicolumn{3}{|c|}{ Moderately affected trees } & \multicolumn{3}{|c|}{ Trees with maximum infection } \\
\hline $\begin{array}{c}\text { Regression } \\
\text { equation }\end{array}$ & $\mathbf{R}^{2}$ & S.E & $\begin{array}{c}\text { Regression } \\
\text { equation }\end{array}$ & $\mathbf{R}^{2}$ & S.E & $\begin{array}{c}\text { Regression } \\
\text { equation }\end{array}$ & $\mathbf{R}^{2}$ & S.E \\
\hline Min.I $=86.6-8.47$ & 39.2 & 8.61 & Mod.I $=6.59+3.50$ & 29.1 & 4.46 & Max.I $=6.80+4.95$ & 37.6 & 5.21 \\
\hline Time $=84.7-10.0$ & 20.5 & & & 15.7 & 4.87 & Time $=8.15+5.70$ & 18.6 & 5.94 \\
\hline $\mathrm{W} \mathrm{T}=68.7+0.0416$ & 0.2 & 11.03 & $\mathrm{~W} \mathrm{~T}=14.1-0.0221$ & 0.2 & 5.29 & $\mathrm{~W} \mathrm{~T}=17.2-0.022$ & 0.2 & 6.59 \\
\hline $\mathrm{RF}=69.5+0.491$ & 0.3 & 11.03 & $\mathrm{RF}=13.6-0.086$ & 0.0 & 5.30 & $\mathrm{RF}=16.9-0.410$ & 0.5 & 6.58 \\
\hline $\mathrm{R} . \mathrm{H}=63.7+0.078$ & 1.1 & 10.98 & $\mathrm{RH}=16.9-0.0432$ & 1.5 & 5.26 & $\mathrm{RH}=19.3-0.0331$ & 0.6 & 6.57 \\
\hline Min. $\mathrm{T}=72.8-0262$ & 2.4 & 10.91 & Mini. $T=12.2+0.120$ & 2.2 & 5.24 & Mini. $\mathrm{T}=15.1+0.139$ & 1.9 & 6.53 \\
\hline Max. $T=77.1+0.273$ & 3.6 & 10.84 & Max. $T=10.4+0.120$ & 3.0 & 5.23 & Max. $T=12.6+0.150$ & 3.1 & 6.49 \\
\hline $\mathrm{WS}=71.1-1.50$ & 2.7 & 10.89 & $\mathrm{WS}=12.9+0.797$ & 3.4 & 5.21 & $\mathrm{WS}=16.0+0706$ & 1.7 & 6.53 \\
\hline
\end{tabular}

WT: Water table; Mini. T: Minimum temperature $\left({ }^{\circ} \mathrm{C}\right)$; Max. T: Maximum temperature $\left({ }^{\circ} \mathrm{C}\right)$; WS: Wind speed (Km/h); RF: Rainfall (mm); Min.I: Trees with minimum infection; Max. I: Maximum infected trees; Mod.I: Moderately infected trees

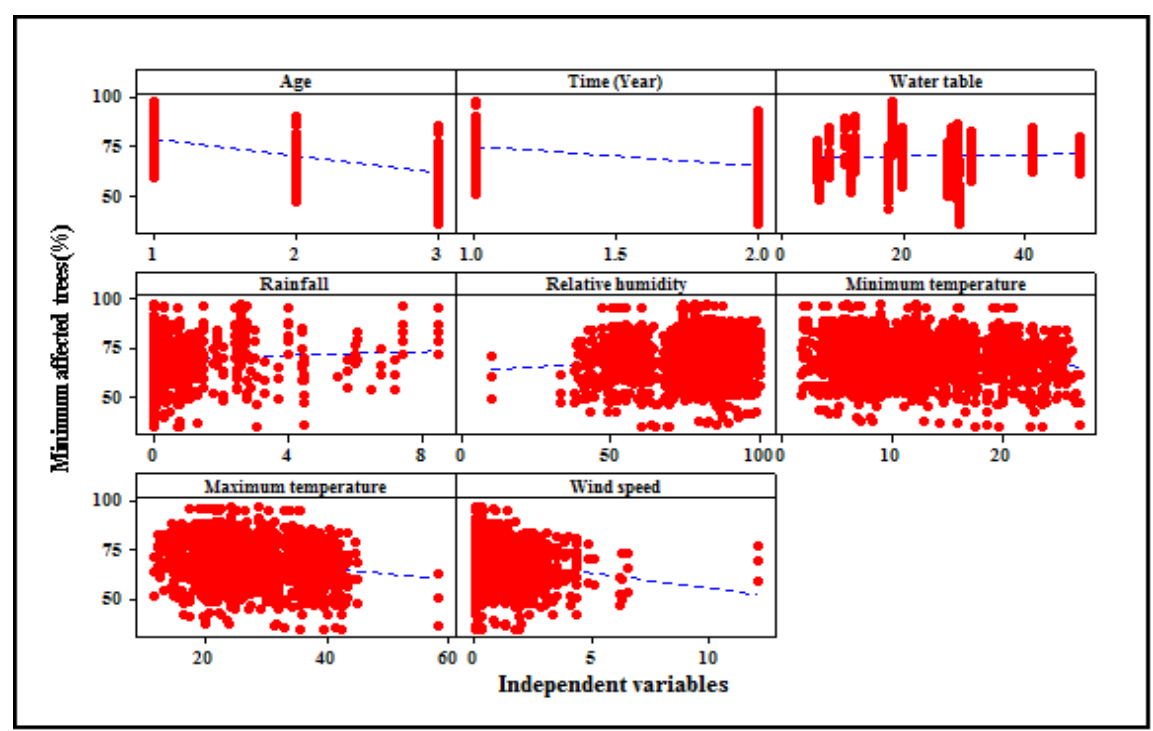

Figure 2. Effect of different environmental variables on proportions of minimum affected D. sissoo trees in Punjab 


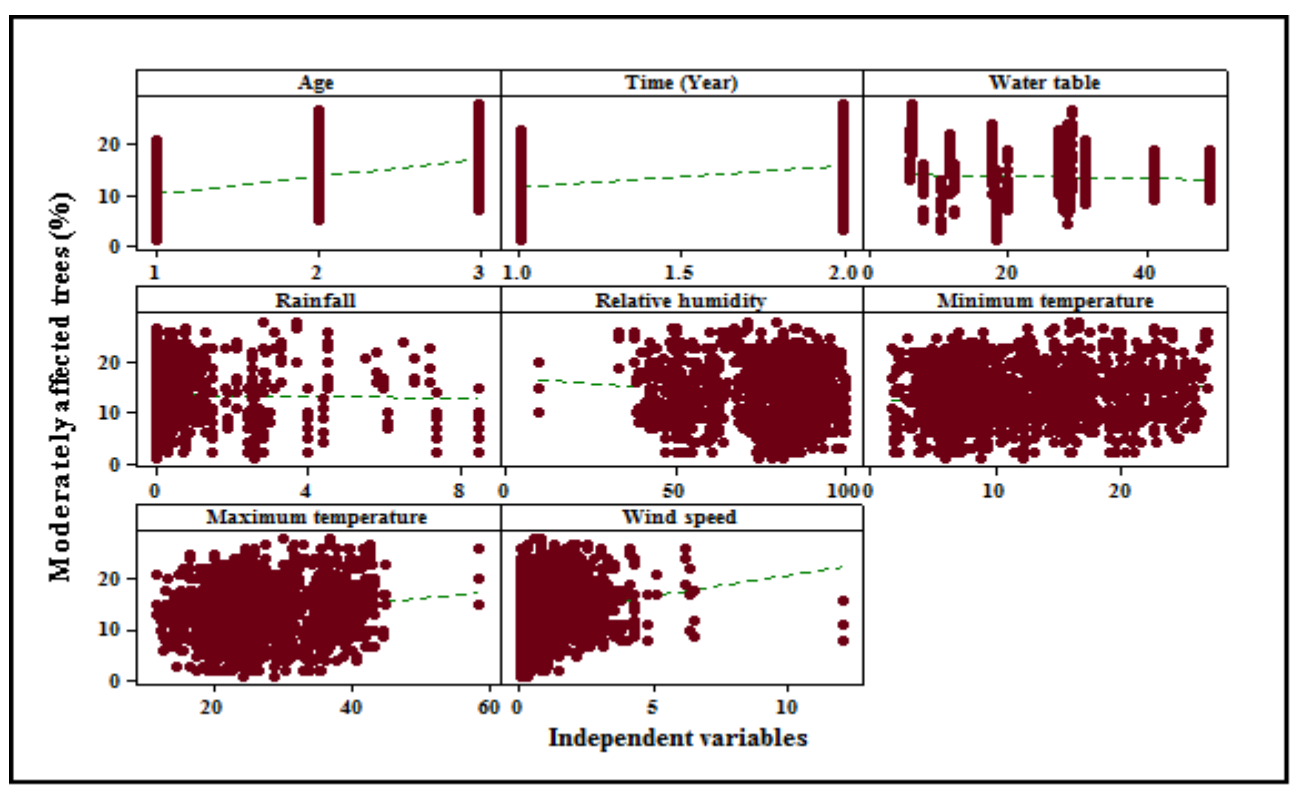

Figure 3. Effect of different environmental variables on proportions of moderately affected D. sissoo trees in Punjab

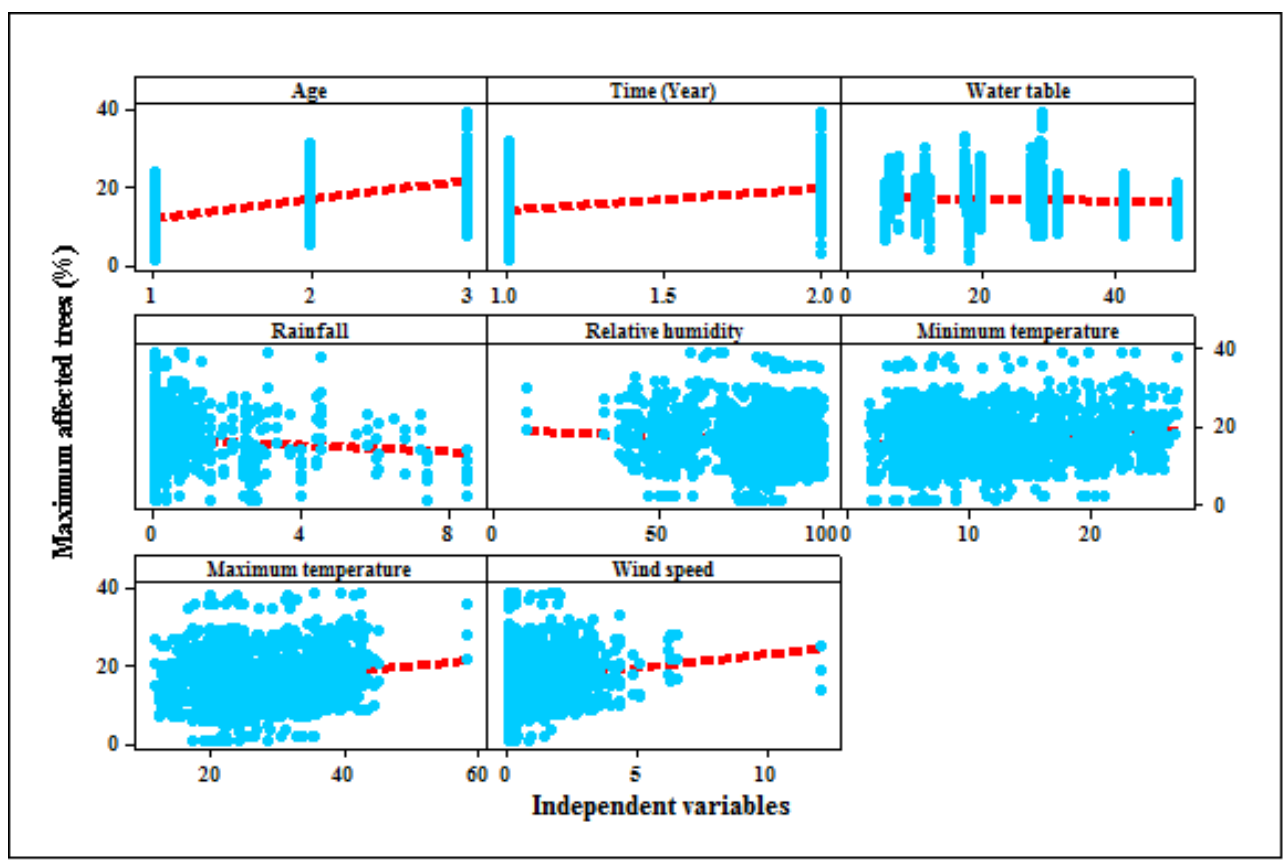

Figure 4. Effect of different environmental variables on proportions of maximum affected D. sissoo trees in Punjab

\section{Dalbergia sissoo dieback disease predictive model based on field survey data}

Data of dead shisham trees due to dieback disease about different categories of host were collected from different shisham grown areas of Punjab (Pakistan) through a comprehensive survey. The effect of host category, environmental variables (Minimum and maximum temperature, rainfall, relative humidity, wind velocity and water table) 
and years (time) on dieback disease development was determined by correlation and regression analysis. A multiple regression model was developed to determine the interrelationships between environmental and the development of dieback disease (Eq. 3). With $\mathrm{R}^{2}$ value of 0.89 , the model was statistically justified at $P<0.05$ and, therefore, can be used to predict the likelihood of dieback occurring under a given set of environmental and other variables.

$$
\begin{aligned}
Y= & 2.51+4.15 x_{1}+5.25 x_{2}+0.00866 x_{3}-0.113 x_{4}-0.0611 x_{5}-0.0115 x_{6} \\
& -0.0092 x_{7}+.0 .514 x_{8}
\end{aligned}
$$

$\mathrm{R}^{2}=0.89, \mathrm{x}_{1}=$ host category, $\mathrm{x}_{2}=$ year (time), $\mathrm{x}_{3}=$ water table, $\mathrm{x}_{4}=$ rainfall, $\mathrm{x}_{5}=$ relative humidity, $\mathrm{x}_{6}=$ minimum temperature, $\mathrm{x}_{7}=$ maximum temperature, $\mathrm{x}_{8}=$ wind velocity.

The model indicated that most predictor variables had a small role in disease development. Age class and time span, however, had an important role. The model equation suggests that with one unit increase in age, dieback incidence will increase by 4.15 units in shisham plantations; with a single unit increase in time span (years), the change in dieback would be 5.25. For rainfall, relative humidity, minimum and maximum temperature, the negative values indicate that an increase in these variables will reduce disease incidence. In the principle component analysis, using the forward selection method, an optimum model was developed. The summary of the forward selection process (Table 2) shows that the partial $\mathrm{R}^{2}$ value after entering the age variable was 0.5253 and for year, relative humidity and wind velocity it was $0.2943,0.0552$ and 0.0154 , respectively. Beyond these variables, there was negligible increase in the $\mathrm{R}^{2}$ value. The $\mathrm{R}^{2}$ value for both the full model and optimum models was the same (0.89).

Then model was evaluated according to the procedures described by the Chaterjee and Hadi (2006) by a) through comparison of the dependent variable (Dieback disease) and regression coefficients with physical theory b) comparison of observed and predicted data.

Table 2. Summary of forward selection

\begin{tabular}{c|c|c|c|c}
\hline Sr\# & Variable entered & $\begin{array}{c}\text { Partial } \\
\text { R-square }\end{array}$ & $\begin{array}{c}\text { Model R- } \\
\text { square }\end{array}$ & Pr $>$ F \\
\hline 1 & Host category (minimum, moderate and maximum infected) & 0.5253 & 0.5253 & $<0.000$ \\
2 & Time (year) & 0.2943 & 0.8196 & $<0.000$ \\
3 & Relative humidity $(\%)$ & 0.0552 & 0.8748 & $<0.000$ \\
4 & Wind speed $(\mathrm{Km} / \mathrm{h})$ & 0.0154 & 0.8902 & $<0.000$ \\
5 & Rainfall $(\mathrm{mm})$ & 0.0009 & 0.8911 & $<0.000$ \\
6 & Water table & 0.0004 & 0.8915 & $<0.023$ \\
7 & Min Temperature $\left({ }^{\circ} \mathrm{C}\right)$ & 0.0003 & 0.8919 & $<0.040$ \\
\hline
\end{tabular}

\section{Comparison of the dependent variable (dieback disease) and regression coefficients with physical theory}

Coefficient of determination $\left(\mathrm{R}^{2}\right)$ was an important parameter derived from the present work. Standard error was good with 1.5532 value (Table 3) The regression model was significant at $\mathrm{P}<0.05$ (Tables 4 and 5). Minimum and maximum 
temperatures were non- significant in the full predictive model. Role of water table and rainfall were also not much significant and summary of forward selection represents the same (Table 2) while all other parameters were significant. In the optimum model age, year, relative humidity and wind velocity were the major contributors in the disease development (Eq. 4). The coefficients, standard error, $\mathrm{t}$ stat and $\mathrm{P}$ values of full and optimum models are given in Tables 3, 4 and 5, respectively. It has been concluded from the above results that the model is very good for prediction.

Optimum predictive model for field data:

$$
\mathrm{Y}=1.65+4.15 \text { Age + 5.20 Year }-0.0523 \mathrm{RH}+0.544 \mathrm{WS}
$$

$\mathrm{R}^{2}=0.89$.

The model was also assessed by comparing the observed and predicted data. Figure 5 shows that majority of the predictions fell between the $95 \%$ confidence intervals and $95 \%$ predictive intervals, demonstrating a very good relationship between predicted and observed data. Based on the $\mathrm{R}^{2}(89 \%)$, the CI and PI model can be used for forecasting the dieback disease of shisham in various climatic conditions in the future.

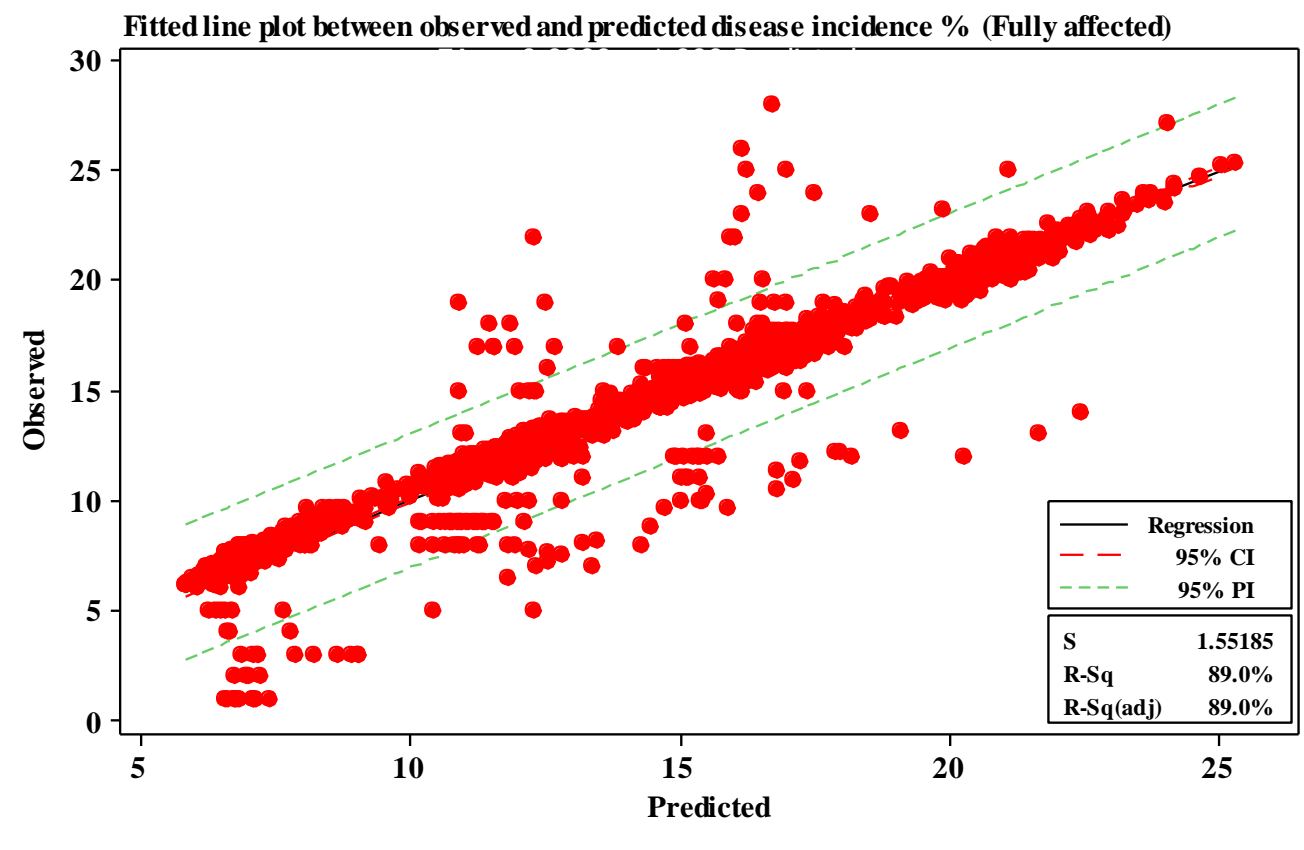

Figure 5. Fitted line plot for dieback disease in maximum affected trees of Shisham with predicted and observed data points at $95 \%$ confidence and predictive interval

Table 3. Regression statistics of optimum predictive model for the maximum infected trees

\begin{tabular}{c|c}
\hline \multicolumn{2}{c}{ Regression statistics } \\
\hline R-square & 0.89 \\
Adjusted R-square & 0.89 \\
Standard error & 1.5532 \\
Observations & 1583 \\
\hline
\end{tabular}


Table 4. ANOVA for optimum predictive model of maximum infected trees

\begin{tabular}{c|c|c|c|c|c}
\hline SOV & Df & SS & MS & F & P value \\
\hline Regression & 4 & 30889.5 & 7722.4 & 3200.57 & $<0.000$ \\
Error & 1579 & 3809.8 & 2.4 & & \\
Total & 1583 & 34699.3 & & & \\
\hline
\end{tabular}

Table 5. Coefficient of variables, standard error, $t$ stat and $P$-value

\begin{tabular}{c|c|c|c|c}
\hline Predictors & Coefficients & Standard error & T stat & P-value \\
\hline Constant & 1.65 & 0.29 & 5.57 & 0.000 \\
Age & 4.15 & 0.047 & 86.91 & 0.000 \\
Year & 5.20 & 0.078 & 66.44 & 0.000 \\
Relative humidity & -0.052 & 0.0029 & -17.62 & 0.000 \\
Wind velocity & 0.54 & 0.036 & 14.87 & 0.000 \\
\hline
\end{tabular}

\section{Discussion}

Dieback is a major threat to D. sissoo and has caused huge damage in all areas where this tree is cultivated. In Pakistan dieback of shisham has been recorded in different regions but severity differs with region (Gill and Aziz, 2004; Ahmad et al., 2016). In present study, a detailed survey of D. sissoo in four different agro-ecological zones of Punjab, Pakistan was conducted and considerable variation was observed in the incidence of dieback disease in the different zones of Punjab. Similar results were reported by Bajwa et al. (2003) from shisham plantations in all regions of Punjab. In present study incidence of disease was observed in different age classes of host (minimum, moderately and maximum infected trees).

The current work showed that tree age, and climatic factors including relative humidity, minimum and maximum temperature and wind velocity, were significantly correlated $(P<0.05)$ with incidence of dieback disease in the different agro-ecological zones. Tree age showed a prominent and strong association with dieback disease in all the examined districts and zones. Amongst the climatic factors, maximum temperature and wind velocity were more important compared to other variables. Baksha and Basak (2000) and Sharma et al. (2000) correlated mortality of D. sissoo with different ages of trees, and found low disease incidence in the early stages of growth, but greater susceptibility in older and larger trees leading to a high mortality rate compared to young plants. These results also support the conclusions of Boland et al. (2004) and Sturrock (2007), Dukes et al. (2009), Tubby and Webber (2010), Timmermann et al. (2017). The disease predictive model developed through regression analysis of the field survey data in this work utilized age class, environmental variables (minimum and maximum temperature, rainfall, relative humidity and wind velocity), time span (years) and underground water table to generate the model. Age class and time span played very important roles in the development of dieback under the field conditions. Hosking and Hutcheson (1992) showed that dieback of Cordyline australis was associated with old trees and attack of pathogens. Acharya and Subedi (2000) reported mortality of over mature dieback affected $D$. sissoo trees in a short period of even few weeks. Phillips et al. (2009) and Allen et al. (2010) observed an increasing trend in forest dieback and mortality due to drought on the basis of literature available from 1984 to 2010. In 1984, 
only $1 \%$ tree mortality was linked with drought, whereas in 2010 the figure was $4 \%$; the value of $\mathrm{R}^{2}=0.61$ in the linear regression model showed a very strong association between tree mortality and drought conditions due to low rainfall and high temperature. These results support the findings reported here, that with the passage of time environmental stresses increased forest mortality. Different researchers (Negi, 2002; Sidhu et al., 2002; Chaudhry, 2006; Thom and Seidl, 2016) observed that the reoccurrence of climatic changes in D. sissoo plantations for more than two years may seriously disturb plant growth and reduce resistance of plants to different pathogens which ultimately causes the death of the trees. These findings are confirmed in this present study.

\section{Conclusions}

Mortality of Dalbergia sissoo due to dieback disease is linked with tree age as disease incidence in different age classes were observed and correlated with various environmental factors. Association was observed between disease and different climatic factors. Varying level of water table in different agro ecological zones of Punjab Province of Pakistan was not considered as a major threat to shisham dieback. Time span in regression equations indicates that with the passage of time disease severity will increase. Farmers and foresters should be careful about the symptoms of disease and harvesting will be a better option for the most affected trees. In future changing climatic conditions of Pakistan can spread disease to least affected areas.

Acknowledgements. We thank Abdul Hannan for guidance with predictive modeling and analysis; Muhammad Kashif, Lecturer Statistics for statistical support; and Amjad Saeed from Punjab Forestry Research Institute, Faisalabad for field assistance. Authors are grateful to the Meteorological Department, Lahore, Punjab for providing climatic data of selected districts.

\section{REFERENCES}

[1] Acharya, K. P., Subedi, N. (2000): A survey on the dieback Dalbergia sissoo in Nepal. Field Document No. 18. - Proc. Sub Regional seminar on Dieback of sissoo (Dalbergia sissoo), Kathmandu, Nepal, pp. 22-25.

[2] Ahmad, I., Khan, R. A., Siddiqui, M. T. (2013): Incidence of dieback disease following fungal inoculations of sexually and asexually propagated shisham (Dalbergia sissoo). Forest Pathology 43(1): 77-82.

[3] Ahmad, I., Gul, S., Hannan, A., Siddiqui, M. T., Nawaz, M. F., Asif, M., Salman, A. (2016): Dieback disease predictive model for sexually and asexually propagated Dalbergia sissoo (Shisham). - Pakistan Journal of Botany 48(4): 1645-1650.

[4] Ahmad, I., Hannan, A.., Ahmad, S., Asif, M., Nawaz, M. F., Tanvir, M. A., Azhar, M. F. (2017): Fungi associated with decline of kikar (Acacia nilotica) and red river gum (eucalyptus Camaldulensis) in Faisalabad. - International Journal of Biological, Biomolecular, Agricultural, Food and Biotechnological Engineering 11(2): 171-174.

[5] Allen, C. D., Macalady, A. K., Chenchouni, H., Bachelet, D., McDowell, N., Vennetier, M., Kitzberger, T., Rigling, A., Breshears, D. D., Hogg, P., Gonzalez, R., Fensham, Z, Zhangm, J., Castro, N., Demidova, J., Hwan Lim, G., Allard, S. W., Running, A., Cobb, N. (2010): A global overview of drought and heat induced tree mortality reveals emerging climate change risks for forests. - Forest Ecology and Management 259: 66084. 
[6] Auclair, A. N. D., Jhon, T., Revenga, C. (2005): The role of climatic variability and global warming in the decline of northern hardwoods. - Water Air Soil Pollution 91: 163186.

[7] Auclair, A. N. D., Heilman, W. E., Blondel, B. (2010): Predicting forest dieback in Maine, USA: a simple model based on soil frost and drought. - Canadian Journal of Forest Research 40: 687-702.

[8] Bajwa, R., Javaid, A., Shah. M. B. M. (2003): Extent of shisham (Dalbergis sissoo) decline in Sialkot, Gujranwala, Lahore and Sargodha districts. - Mycopathology 1: 1-5.

[9] Baksha, M. W., Basak, A. C. (2000): Mortality of sissoo (Dalbergia sissoo) in Bangladesh. Field Document No. 18. - Proc. Sub Regional seminar on Dieback of sissoo (Dalbergia sissoo), Kathmandu, Nepal, pp. 1-4.

[10] Boland, G. J., Melzer, M. S., Hopkin, A., Higgins, V., Nassuth, A. (2004): Climate change and plant diseases in Ontario. - Canadian Journal of Plant Pathology 26: 335-350.

[11] Boyd, I. L., Freer-Smith, P. H., Gilligan, C. A., Godfray, H. C. J. (2013): The consequences of tree pests and diseases for ecosystem services. - Science 342: 1235773.

[12] Chatterjee, S., Hadi, A. S. (2006): Regression Analysis by Example. Fourth Ed. - John Wiley and Sons, Chichester.

[13] Chaturvedi, O. P., Ali, M. S., Das, D. K. (2002): Studies on Shisham Mortality and Its Management in Bihar. - Department of Forestry and Natural Resources Punjab Agricultural University, Ludhiana, pp. 22-25.

[14] Chaudhary, A. K. (2006): Abiotic and biotic stresses on shisham trees. - Proc. of the Second National Seminar on Shisham Dieback, June 29, 2004. Punjab Forestry Research Institute, Faisalabad, pp. 111-118.

[15] Ciesla, W. M., Donaubauer. M. E. (1994): Decline and dieback of trees and forests: a global overview. - FAO Forestry Paper 120: 90.

[16] Clatterbuck, W. K. (2006): Dieback and Decline of Trees. - University of Tennessee, Agricultural Extension Service, Knoxville.

[17] Dukes, J. S., Pontius, J., Orwig, D. (2009): Responses of insect pests, pathogens, and invasive plant species to climate change in the forests of northeastern North America: what can we predict. - Canadian Journal of Forest Research 39: 231-248.

[18] Farooq, T. H., Gautam, N. P., Rashid, M. H. U., Gillani, M. M., Nemin, W., Nawaz, M. F., Islam, W., Zainab, M., Wu, P. (2018): Contributions of agroforestry on socioeconomic conditions of farmers in central Punjab, Pakistan - a case study. - Cercetări Agronomice în Moldova 2: 91-101.

[19] Gill, M. A., Aziz, T. (2004): Evaluation of soil properties for their role in shisham dieback. In proceedings of second National seminar on Shisham dieback. - Punjab Forestry Research Institute Faisalabad 36-39.

[20] Hosking, G. P. (1989): Beech forest health- implications for management. - New Zealand Journal of Forestry Science 19: 290-293.

[21] Hosking., Hutcheson, J. A. (1992): Sudden Decline of Cabbage Tree (ti kouka) - How Bad, How Extensive? What's New in Forest Research no 227. - Zealand Forest Research Institute, Rotorua.

[22] Jump, A., Hunt, J. M., Peñuelas, J. (2006): Rapid climate change-related growth decline at the southern range edge of Fagus sylvatica. - Global Change Biology 12: 2163-2174.

[23] Jurskis, V. (2004): Overview of forest decline in coastal New South Wales. - Proc. Colloquium at Batemans, Bay Sydney, Australia, pp. 4-7.

[24] Kaushal, P., Banyal, R., Kant, C. (2002): - Role of climatic conditions on mortality of Kikar and shisham in Punjab. In Proc: Regional Symposium on Mortality of Shisham and Kikar in Northern States of India. Gill, S. S., Chauhan, S. K., Khajuria, H. N., Dhanda, R.S., Chauhan, R. (eds.). March 3-4, 2002. Punjab Agriculture University, Ludhiana, pp. 51-64.

[25] Khan, M. A., Ilayas, M. B. (1999): A two environmental variable model to forecast leaf rust on wheat. - Proceeding of $2^{\text {nd }}$ National Conference PIant Pathology, pp. 72-89. 
[26] Khan, A. I., Khan, A., Asif, H., Jiskani, M. M., Muhlbach, H. P., Azim, M. K. (2014): Isolation and 16s rDNA sequence analysis of bacteria from dieback affected mango orchards in southern Pakistan. - Pakistan Journal of Botany 46: 1431-1435.

[27] Lal, H. S., Singh, S. (2012): Ethnomedicinal uses of Dalbergia sissoo Roxb in Jharkhand. - International Journal of Ayurvedic \& Herbal Medicine 2(1): 198-201.

[28] Lowman, M. D. (1991): The dieback crisis - tree declines throughout the world. - Centre for Environmental Studies Journal, Williams College, pp. 28-31.

[29] National Research Council (2001): Economic and Ecological Impacts of Abrupt Climate Change. - In: Committee on Abrupt Climate Change, Ocean Studies Board, Polar Research Board, Board on Atmospheric Sciences and Climate (eds.) Abrupt Climate Change: Inevitable Surprises. National Research Council, Washington, DC, Chapter 5, pp. 90-117.

[30] Negi, J. D. S. (2002): Shisham Mortality in India - Case Study. - Department of Forestry and Natural Resources Punjab Agricultural University, Ludhiana 19-21.

[31] Nepstad, D. C., Stickler, C. M., Soares-Filho, B., Merry, F. (2008): Interactions among Amazon land use, forests and climate: prospects for a near-term forest tipping point. Philosophical Transcripts of the Royal Society of London, Series B 363: 1737-1746.

[32] Phillips, O. L., Aragão, L. E. O. C., Lewis, S. L., Fisher, J. B., Lloyd, J., pez-González, G., Ló Malhi, Y., Monteagudo, A., Peacock, J., Quesada, C. A., van der Heijden, G., Almeida, S., Amaral, I., Arroyo, L., Aymard, G., Baker, T. R., Bánki, O., Blanc, L., Bonal, D., Brando, P., Chave, J., Alves de Oliveira, A. C., Dávila Cardozo, N., Czimczik, C. I., Feldpausch, T. R., Freitas, M. A., Gloor, E., Higuchi, N., Jiménez, E., Lloyd, G., Meir, P., Mendoza, C., Morel, A., Neill, D. A., Nepstad, D., Patinão, S., Peñuela, M. C., Prieto, A., Ramírez, F., Schwarz, M., Silva, J., Silveira, M., SotaThomas, A., Ter Steege, H., Stropp, J., Vásquez, R., Zelazowski, P., Alvarez Dávila, E., Andelman, S., Andrade, A., Chao, K., Erwin, T., Di Fiore, A., Honorio, C., Keeling, E., Killeen, H., Laurance, T. J., Peña Cruz, W. F., Pitman, A., Núñez Vargas, N. C. A., Ramírez-Angulo, P., Rudas., Salamão, H., Silva, R., Terborgh, N., Torres- Lezama, J. A. (2009): Drought sensitivity of the Amazon rainforest. - Science 323: 1344-1347.

[33] Rajput, N. A., Pathan, M. A., Jiskani, M. M., Rajput, A. Q., Arain, R. R. (2008): Pathogenecity and host range of Fusarium solani (MART) SACC. Causing dieback of shisham (Dalbergia sissoo ROXB.). - Pakistan Journal of Botany 40(6): 2631-2639.

[34] Rashid, M. H. U., Asif, M., Farooq, T. H., Gautam, N. P., Nawaz, M. F., Ahmad, I., Gilani, M. M., Wu, P. (2019): Cuttings growth response of Dalbergia Sissoo (Shisham) to soil compaction stress. - Applied Ecology and Environmental Research. DOI: http://dx.doi.org./10.15666/aeer/1701_10491059.

[35] Raza, M. M., Khan, M. A., Ahmad, I., Bajwa, A. A., Aslam, H., Ullah, B. A., Riaz, K. (2015): Forest pathogens and diseases under changing climate-a review. - Pakistan Journal of Agricultural Research 28: 318-337.

[36] Sharma, M. K., Singhal, R. M., Pokhariyal, T. C. (2000): Dalbergia sissoo in India. Field Document No. 18. - Proc. Sub Regional Seminar on Dieback of Sissoo (Dalbergia sissoo), Kathmandu, Nepal.

[37] Simpson, P. (1993): The Cabbage Trees (Cordyline australis) are Dying: Investigations of Sudden Decline in New Zealand. - In: Huetti, R. F., Muller-Dombois, D. (eds.) Forest Decline in the Atlantic and Pacific Region. Springer-Verlag, Berlin and Heidelberg, pp. 280-292.

[38] Sidhu, D. S., Dhillon, G. P. S., Singh, B. (2002): Shisham Mortality and Its Remedial Measures through Genetic Manipulations. Mortality of Shisham and Kikar in India. Department of Forestry and Natural Resources, Punjab Agricultural University, Ludhiana, pp. 31-36.

[39] Singh, S. (1980): Shisham (Dalbergia sissoo) mortality and its remedial measure through genetic manipulations. - Proc. Regional Symposium on Mortality of Shisham and Kikar in Northern States of India. March 3-4, 2002. Punjab Agriculture University, Ludhiana. 
[40] Sperry, J. S., Perry, A. H., Sullivan, J. E. M. (1991): Pit membrane degradation and airembolism formation in ageing xylem vessels of Populus tremuloides Michx. - Journal of Experimental Botany 42(11): 1399-1406.

[41] Steel, R. G. D., Torrie, J. H., Dicky, D. A. (1997): Principles and Procedures of Statistics. A Biometrical Approach. $3^{\text {rd }}$ Ed. - McGraw Hill Book Co., New York.

[42] Sturrock, R. N. (2007): Climate change effects on forest diseases: an overview. - Proc. $54^{\text {th }}$ Annual Western International Forest Disease Work Conf, Smithers, British Columbia, 2-6 October, 2006.

[43] Sturrock, R. N., Frankel, S. J., Frankel, J., Brown, A. V., Hennon, P. E., Lliejunas, J. T., Lewis, K. J., Worrall, J. J., Woods, J. (2011): Climate change and forest diseases. - Plant Pathology 60: 133-149.

[44] Thom, D., Seidl, R. (2016): Natural disturbance impacts on ecosystem services and biodiversity in temperate and boreal forests. - Biological Reviews 91: 760-781.

[45] Timmermann, V., Nagy, N. E., Hietala, A. M., Børja, I., Solheim, H. (2017): Progression of ash dieback in Norway related to tree age, disease history and regional aspects. - Baltic Forestry 23: 150-158.

[46] Tubby, K. V., Webber, J. F. (2010): Pests and diseases threatening urban trees under a changing climate. - Forestry 83: 451-459.

[47] Vogel, S., Tantau, H., Mielke-Ehret, N., Hoque, M. I., Sarker, R. H., Saha, M. L., Alam, S. K. S., Khan, S., Muhlbach, H. P. (2010): Detection of virus particles and double stranded RNA in dieback affected Dalbergia sissoo from Bangladesh. - Bangladesh Journal of Botany 40: 57-65. 